\title{
The Impact of Environmental Policy on Low-Carbon Technology Innovation Performance of Chinese Manufacturing Industry
}

\author{
Qun Fang \\ Harbin University of Science and Technology, Harbin, Heilongjiang Province, China \\ vickie361@163.com
}

\begin{abstract}
Keywords: Environmental Policy, low-carbon technology innovation, innovation performance, structural equation model.

Abstract. In this paper, taking the low-carbon technology innovation enterprise in China as the research sample, we design a questionnaire survey and obtain relevant data and develop the relationship between environmental protection policy and manufacturing low carbon technology innovation performance. By Using of structural equation model and AMOS17.0 software to deal with data, we verify the effect of environmental policy on the innovation performance of low-carbon technology in China which has concluded with a practical sense.
\end{abstract}

\section{Introduction}

In recent years, low-carbon economy marked by-low energy consumption, low-emission, low-pollution has become a new trend in the global socio-economic development [1], and low-carbon technology innovation is the core of greenhouse gas emissions [2], and the fundamental way to achieve low-carbon economy. Chinese manufacturing in the low-end manufacturing sectors of low value-added and high-polluting, is not only beared the enormous damage to the environment caused by energy consumption, but also facing the problem that manufacturing enterprises are being squeezed by the multi-national corporation to use its core competitiveness, which makes the profit margins of China's manufacturing industry becoming smaller and smaller. Therefore, the subject about how to achieve the equilibrium of low-carbon manufacturing technology innovation and environmental protection, has increasingly become a hot issue in domestic academia that caused long-term attention and research. In this paper, we will study the impact of various environmental policies on the innovation performance of China's manufacturing industry.

\section{Theory basis and research hypothesis}

Environmental Policy. Combined with domestic and foreign scholars' points of view on environmental policy, this article divides environmental policy into imperative environmental policy, voluntary environmental policy and incentive environmental policy. Imperative environmental policy refers to the government through the development of the corresponding policy, requiring enterprises to meet the basic requirements of environmental regulations, with mandatory, which will make the enterprise tend to have a negative attitude. Voluntary environmental policy refers to the enterprises actively participate in environmental regulation, and volunteered to perform a variety of environmental regulation policy. Incentive environmental policy emphasizes the role of government in regulating effect that aimed at with the help of the double aspect of market and government, to promote enterprise implementation of environmental regulation policy.

Low-carbon Technology Innovation Performance. Technical innovation performance, Gao Jian (2004) to mean efficiency, effectiveness, and outputs results of enterprise technology innovation process to the contribution of commercial success, and generally include process performance and output performance [3]. Innovation performance is not only a process, but also affected by a variety of factors. Low-carbon technology innovation performance is the efficiency and effectiveness of controlling and reducing the process of carbon emissions. This article divides low-carbon technology 
innovation performance into three dimensions: low-carbon R\&D performance, low-carbon manufacturing performance, low-carbon marketing performance.

Hypothesis. Chinese manufacturing industry is still in the low-end manufacturing sectors of low value-added and high-polluting, while the path dependence of the traditional development model based on fossil energy is formed, which is restricted by many factors in the development process.. Therefore, this paper believes that environmental policy has an important impact on the manufacturing low-carbon technology innovation. Based on previous studies of the activity of Chinese manufacturing low-carbon technology innovation and current relevant research of environmental policy impact on manufacturing low-carbon technology innovation performance, this paper proposes the following hypothesis:

Hypothesis 1. Imperative environmental policy has a significant positive effect on low-carbon R\&D performance.

Hypothesis 2. Imperative environmental policy has a significant positive effect on low-carbon manufacturing performance.

Hypothesis 3. Imperative environmental policy has a significant positive effect on low-carbon marketing performance.

Hypothesis 4. Voluntary environmental policy has a significant positive effect on low-carbon R\&D performance.

Hypothesis 5. Voluntary environmental policy has a significant positive effect on low-carbon manufacturing performance.

Hypothesis 6. Voluntary environmental policy has a significant positive effect on low-carbon marketing performance.

Hypothesis 7. Incentive environmental policy has a significant positive effect on low-carbon R\&D performance.

Hypothesis 8. Incentive environmental policy has a significant positive effect on low-carbon manufacturing performance.

Hypothesis 9. Incentive environmental policy has a significant positive effect on low-carbon marketing performance.

\section{Research Methods}

Sample Selection and Data Sources. This paper selects domestic manufacturing enterprises with representative innovation as research samples. Data were collected by questionnaires, the respondent include: (1)Charge of government environmental policy departments and related departments; (2) Relevant person in charge of low-carbon technology innovation enterprises; (3)Social well-known experts and scholars. Meanwhile, this paper chooses Hangzhou, Shanghai, Beijing and other regions where the manufacturing low-carbon technology innovation enterprises are concentrated that to ensure the smooth progress of the questionnaire and the effectiveness of findings of the survey.

Questionnaire method using Likert (Likert) of the standard five-point scale, 1 represents totally disagree, 2 represents most disagree, 3 represents basically agree, 4 represents most agree, 5 represents totally agree. A total of 500 questionnaires were returned of 321 copies, of which 259 valid questionnaires, the effective rate is $80.69 \%$. Questionnaire designed by using the method of combining multiple title and item to improve the reliability and validity of metrics [4].

Variable Measurements. Now a lot of relevant literature, designed the relationship scale between environmental policy and manufacturing low-carbon technology innovation performance (Table 1).

Environmental Policy Variables. In the case of variable of questions of measurement consistency, multiple questions have higher reliability than the individual questions. So we use multiple questions to measure environmental policy variables. Combined with the characteristics of environmental policy and the actual situation of corporate research and expert opinion, we assigned $\mathrm{A}_{11}-\mathrm{A}_{14}$ measuring imperative environmental policy, $\mathrm{B}_{11}-\mathrm{B}_{15}$ measuring voluntary environmental policy and $\mathrm{C}_{11}-\mathrm{C}_{13}$ measuring incentive environmental policy. Through the analysis of the factors of 
the above 12 measurement variables, we know that three factors with eigenvalues are greater than $1(7.023,1.081$ and 1.005$)$, which account for a total of $67.895 \%$ of the total variance. This states that questions of measuring the composition of the three factors, which consistent with the theoretical assumptions of this paper.

Table 1. Variable description

\begin{tabular}{|c|c|c|c|}
\hline \multicolumn{2}{|c|}{ Variable } & Code & Questions of measurement \\
\hline \multirow{12}{*}{$\begin{array}{l}\text { Environmental } \\
\text { Policy }\end{array}$} & \multirow{4}{*}{$\begin{array}{c}\text { Imperative } \\
\text { environmental } \\
\text { policy }\end{array}$} & $\mathrm{A}_{11}$ & $\begin{array}{l}\text { Laws and regulations on environmental regulation established whether is } \\
\text { perfect }\end{array}$ \\
\hline & & $A_{12}$ & $\begin{array}{l}\text { Policies and systems of environmental regulation developed whether is } \\
\text { perfect }\end{array}$ \\
\hline & & $A_{13}$ & $\begin{array}{l}\text { Technical standards, emission standards of environmental regulations set } \\
\text { whether is perfect }\end{array}$ \\
\hline & & $\mathrm{A}_{14}$ & $\begin{array}{l}\text { In violation of the relevant provisions of environmental regulations } \\
\text { whether to be punished }\end{array}$ \\
\hline & \multirow{5}{*}{$\begin{array}{c}\text { Voluntary } \\
\text { environmental } \\
\text { policy }\end{array}$} & $\mathrm{B}_{11}$ & $\begin{array}{l}\text { Whether willing to publish regularly environmental information to } \\
\text { industry }\end{array}$ \\
\hline & & $\mathrm{B}_{12}$ & $\begin{array}{l}\text { Whether to abide voluntarily by environmental standards required by the } \\
\text { industry }\end{array}$ \\
\hline & & $\mathrm{B}_{13}$ & Whether to implement cleaner production \\
\hline & & $\mathrm{B}_{14}$ & Whether to hold regular environmental meetings, listen to expert advice \\
\hline & & $\mathrm{B}_{15}$ & Whether to pass national regulations ISO14000 certification \\
\hline & \multirow{3}{*}{$\begin{array}{c}\text { Incentive } \\
\text { environmental } \\
\text { policy }\end{array}$} & $\mathrm{C}_{11}$ & $\begin{array}{l}\text { Whether compliance with environmental regulations related policies will } \\
\text { be certain subsidies }\end{array}$ \\
\hline & & $\mathrm{C}_{12}$ & Whether environmental regulation will be saving technology support \\
\hline & & $\mathrm{C}_{13}$ & Whether environmental regulation will be certain tax incentives \\
\hline \multirow{8}{*}{$\begin{array}{l}\text { Low-carbon } \\
\text { Technology } \\
\text { Innovation } \\
\text { Performance }\end{array}$} & \multirow{3}{*}{$\begin{array}{l}\text { Low-carbon } \\
\text { R\&D } \\
\text { performance }\end{array}$} & $\mathrm{D}_{11}$ & $\begin{array}{l}\text { Whether to increase the staff input of manufacturing low-carbon } \\
\text { technology innovation }\end{array}$ \\
\hline & & $D_{12}$ & $\begin{array}{l}\text { Whether to increase the funding input of manufacturing low-carbon } \\
\text { technology innovation }\end{array}$ \\
\hline & & $\mathrm{D}_{13}$ & $\begin{array}{l}\text { Whether to increase the number of effective patents internationally } \\
\text { mandated of manufacturing low-carbon technology }\end{array}$ \\
\hline & \multirow{3}{*}{$\begin{array}{l}\text { Low-carbon } \\
\text { manufacturing } \\
\text { performance }\end{array}$} & $E_{11}$ & Whether to increase production scale manufacturing low-carbon products \\
\hline & & $\mathrm{E}_{12}$ & $\begin{array}{l}\text { Whether to reduce manufacturing enterprises fossil energy consumption } \\
\text { per unit of output }\end{array}$ \\
\hline & & $E_{13}$ & $\begin{array}{l}\text { Whether to reduce carbon emission intensity of manufacturing } \\
\text { enterprises }\end{array}$ \\
\hline & \multirow{2}{*}{$\begin{array}{l}\text { Low-carbon } \\
\text { marketing } \\
\text { performance }\end{array}$} & $\mathrm{F}_{11}$ & $\begin{array}{l}\text { Whether to take advantage of existing marketing channels of } \\
\text { manufacturing low-carbon products }\end{array}$ \\
\hline & & $\mathrm{F}_{12}$ & $\begin{array}{l}\text { Whether to increase the international market share of manufacturing } \\
\text { low-carbon products }\end{array}$ \\
\hline
\end{tabular}

Low-carbon Technology Innovation Performance Variables. Based on theoretical analysis, we assigned $\mathrm{D}_{11}-\mathrm{D}_{13}$ measuring low-carbon $\mathrm{R} \& \mathrm{D}$ performance, $\mathrm{E}_{11}-\mathrm{E}_{13}$ measuring low-carbon manufacturing performance, and $\mathrm{F}_{11}-\mathrm{F}_{12}$ measuring low-carbon marketing performance. For above eight measured variables with factor analysis, we found that there are three factors with eigenvalues greater than 1, respectively 5.621, 1.265 and 1.022, which account for a total of $69.856 \%$ of the total variance. This shows that questions of measuring the composition of the three factors, which consistent with the theoretical assumptions of this paper.

Reliability and Validity. Reliability refers to the consistency or stability between each measurement, the higher the reliability the smaller the error. The observation values will not change in the form and time of measurement, and the stability is high. Cronbach's $\alpha$ coefficient test is commonly used to measure the reliability in the Likert attitude scale, and usually considered $\alpha$ values greater than 0.7 . The analysis of each factor with SPSS21.0 obtained reliability coefficients greater than 0.7 , indicating that the survey has a high reliability (Table 2).

Validity main evaluates the accuracy, validity or correctness of questionnaire survey accuracy, the higher validity results of the measurement show the more true qualities of the object to be measured. 
Based on the results of factor analysis, the factor loadings of both three dimensions of environmental policy and three dimensions of low-carbon technology innovation performance were greater than 0.5 , indicating that they have relatively high efficiency degree (Table 3 and Table 4).

Table 2. Survey questionnaire reliability test

\begin{tabular}{|c|c|c|c|}
\hline Variable & Observed variables & Number & Cronbach's $\boldsymbol{\alpha}$ \\
\hline \multirow{2}{*}{$\begin{array}{c}\text { Environmental } \\
\text { Policy }\end{array}$} & Imperative environmental policy & 4 & 0.916 \\
\cline { 2 - 4 } & Voluntary environmental policy & 5 & 0.886 \\
\cline { 2 - 4 } & Incentive environmental policy & 3 & 0.929 \\
\hline Low-carbon & Low-carbon R\&D performance & 3 & 0.839 \\
\cline { 2 - 4 } $\begin{array}{c}\text { Technology } \\
\text { Innovation }\end{array}$ & Low-carbon manufacturing performance & 3 & 0.825 \\
\cline { 2 - 4 } Performance & Low-carbon marketing performance & 2 & 0.779 \\
\hline
\end{tabular}

Table 3. After the rotation of factor loadings matrix questions of environmental policy

\begin{tabular}{|c|c|c|c|c|}
\hline & \multicolumn{3}{|c|}{ Component } \\
\hline & & 1 & 2 & 3 \\
\hline \multirow{4}{*}{$\begin{array}{l}\text { Imperative environmental } \\
\text { policy }\end{array}$} & $\mathrm{A}_{11}$ & 0.787 & 0.105 & 0.112 \\
\hline & $\mathrm{A}_{13}$ & 0.773 & 0.142 & 0.237 \\
\hline & $\mathrm{A}_{12}$ & 0.761 & 0.152 & 0.105 \\
\hline & $\mathrm{A}_{14}$ & 0.739 & 0.201 & 0.179 \\
\hline \multirow{5}{*}{$\begin{array}{l}\text { Voluntary environmental } \\
\text { policy }\end{array}$} & $\mathrm{B}_{13}$ & 0.105 & 0.821 & 0.133 \\
\hline & $\mathrm{B}_{12}$ & 0.268 & 0.775 & 0.309 \\
\hline & $\mathrm{B}_{11}$ & 0.125 & 0.773 & 0.033 \\
\hline & $\mathrm{B}_{15}$ & 0.136 & 0.758 & 0.237 \\
\hline & $\mathrm{B}_{14}$ & 0.106 & 0.728 & 0.045 \\
\hline \multirow{3}{*}{$\begin{array}{l}\text { Incentive environmental } \\
\text { policy }\end{array}$} & $\mathrm{C}_{11}$ & 0.098 & 0.106 & 0.828 \\
\hline & $\mathrm{C}_{12}$ & 0.155 & 0.157 & 0.797 \\
\hline & $\mathrm{C}_{13}$ & 0.238 & 0.077 & 0.723 \\
\hline
\end{tabular}

Table 4. After the rotation of factor loadings matrix questions of low-carbon technology innovation performance

\begin{tabular}{|c|c|c|c|c|}
\hline \multicolumn{2}{|c|}{} & \multicolumn{3}{|c|}{ Component } \\
\cline { 3 - 5 } \multicolumn{2}{|c|}{} & $\mathbf{1}$ & $\mathbf{2}$ & $\mathbf{3}$ \\
\hline \multirow{2}{*}{$\begin{array}{c}\text { Low-carbon R\&D } \\
\text { performance }\end{array}$} & $\mathrm{D}_{12}$ & 0.775 & 0.101 & 0.118 \\
\cline { 2 - 5 } & $\mathrm{D}_{11}$ & 0.737 & 0.155 & 0.165 \\
\cline { 2 - 5 } & $\mathrm{D}_{13}$ & 0.722 & 0.205 & 0.181 \\
\hline \multirow{2}{*}{$\begin{array}{c}\text { Low-carbon } \\
\text { manufacturing } \\
\text { performance }\end{array}$} & $\mathrm{E}_{12}$ & 0.092 & 0.820 & 0.125 \\
\cline { 2 - 5 } & $\mathrm{E}_{13}$ & 0.137 & 0.761 & 0.077 \\
\cline { 2 - 5 } & $\mathrm{E}_{11}$ & 0.202 & 0.736 & 0.213 \\
\hline $\begin{array}{c}\text { Low-carbon } \\
\text { manufacturing } \\
\text { performance }\end{array}$ & $\mathrm{F}_{12}$ & 0.078 & 0.276 & 0.785 \\
\cline { 2 - 5 } & $\mathrm{F}_{11}$ & 0.245 & 0.128 & 0.752 \\
\hline
\end{tabular}

\section{Research Result}

Descriptive Statistics and Correlation Analysis. Using SPSS21.0 to analyze the content of the questionnaire and correlation analysis, the results of the analysis are shown in Table 5, table 6. Based on the average of the variables, the mean of imperative environmental policy is maximum, shows that Chinese environmental policy is still commands, coercion and control methods based mainly enterprises have small voluntary to environmental policy, effective incentive environmental policy to improve low-carbon technologies innovation performance have a role in promoting. The mean of both low-carbon manufacturing performance and low-carbon marketing performance are more than the mean of low-carbon R\&D performance, indicating environmental policy to improve the level of manufacturing low-carbon technology innovation play a significant role, and having made 
tremendous contributions to environmental protection and technological innovation. From the correlation analysis of variables, between voluntary environmental policy, incentive environmental policy and low-carbon R\&D performance, low-carbon manufacturing performance, low-carbon marketing performance have significantly positive correlation, and initially verified the hypothesis of this study.

Table 5. Statistical description

\begin{tabular}{|c|c|c|c|c|c|}
\hline \multicolumn{2}{|r|}{ Variable } & Code & Mean & & DX \\
\hline \multirow{12}{*}{$\begin{array}{l}\text { Environmental } \\
\text { Policy }\end{array}$} & \multirow{4}{*}{$\begin{array}{l}\text { Imperative } \\
\text { environmental policy }\end{array}$} & $\mathrm{A}_{11}$ & 3.3789 & \multirow{4}{*}{3.3277} & 0.9298 \\
\hline & & $\mathrm{A}_{12}$ & 3.2538 & & 0.8789 \\
\hline & & $\mathrm{A}_{13}$ & 3.2467 & & 0.9501 \\
\hline & & $\mathrm{A}_{14}$ & 3.4315 & & 0.9506 \\
\hline & \multirow{5}{*}{$\begin{array}{l}\text { Voluntary environmental } \\
\text { policy }\end{array}$} & $\mathrm{B}_{11}$ & 3.1821 & \multirow{5}{*}{3.2511} & 0.9784 \\
\hline & & $\mathrm{B}_{12}$ & 3.2353 & & 0.9523 \\
\hline & & $\mathrm{B}_{13}$ & 3.0356 & & 0.9897 \\
\hline & & $\mathrm{B}_{14}$ & 3.1812 & & 0.9924 \\
\hline & & $\mathrm{B}_{15}$ & 3.6214 & & 0.8512 \\
\hline & \multirow{3}{*}{$\begin{array}{l}\text { Incentive environmental } \\
\text { policy }\end{array}$} & $\mathrm{C}_{11}$ & 3.2321 & \multirow{3}{*}{3.2842} & 0.8690 \\
\hline & & $\mathrm{C}_{12}$ & 3.2705 & & 0.8590 \\
\hline & & $\mathrm{C}_{13}$ & 3.3501 & & 0.8200 \\
\hline \multirow{8}{*}{$\begin{array}{l}\text { Low-carbon } \\
\text { Technology } \\
\text { Innovation } \\
\text { Performance }\end{array}$} & \multirow{3}{*}{$\begin{array}{l}\text { Low-carbon R\&D } \\
\text { performance }\end{array}$} & $D_{11}$ & 3.4802 & \multirow{3}{*}{3.3697} & 0.9088 \\
\hline & & $D_{12}$ & 3.2703 & & 0.9400 \\
\hline & & $\mathrm{D}_{13}$ & 3.3587 & & 0.9188 \\
\hline & \multirow{3}{*}{$\begin{array}{l}\text { Low-carbon } \\
\text { manufacturing } \\
\text { performance }\end{array}$} & $E_{11}$ & 3.3998 & \multirow{3}{*}{3.4350} & 0.7960 \\
\hline & & $E_{12}$ & 3.4021 & & 0.7590 \\
\hline & & $E_{13}$ & 3.5032 & & 0.7400 \\
\hline & \multirow{2}{*}{$\begin{array}{c}\text { Low-carbon marketing } \\
\text { performance }\end{array}$} & $\mathrm{F}_{11}$ & 3.3285 & \multirow{2}{*}{3.4627} & 0.9968 \\
\hline & & $\mathrm{F}_{12}$ & 3.5968 & & 0.8678 \\
\hline
\end{tabular}

Table 6. Correlation analysis variables

\begin{tabular}{|l|c|c|c|c|c|c|c|}
\hline \multicolumn{2}{|c|}{ Variable } & $\mathbf{1}$ & $\mathbf{2}$ & $\mathbf{3}$ & $\mathbf{4}$ & $\mathbf{5}$ & $\mathbf{6}$ \\
\hline $\mathbf{1}$ & Imperative environmental policy & 1 & & & & & \\
\hline $\mathbf{2}$ & Voluntary environmental policy & 0.052 & 1 & & & & \\
\hline $\mathbf{3}$ & Incentive environmental policy & 0.035 & 0.065 & 1 & & & \\
\hline $\mathbf{4}$ & Low-carbon R \& D performance & 0.151 & $0.658^{*}$ & $0.658^{*}$ & 1 & & \\
\hline $\mathbf{5}$ & Low-carbon manufacturing performance & 0.099 & $0.678^{*}$ & $0.726^{*}$ & 0.052 & 1 & \\
\hline $\mathbf{6}$ & Low-carbon marketing performance & 0.079 & $0672^{*}$ & $0.855^{*}$ & 0.131 & 0.078 & 1 \\
\hline
\end{tabular}

Output result analysis. Using AMOS17.0 software to analyze the structural equation of the survey data, the analysis results (shown in figure 1) of data input and output in AMOS17.0, shows the model reached a good fitting degree that can be seen from table 7 .

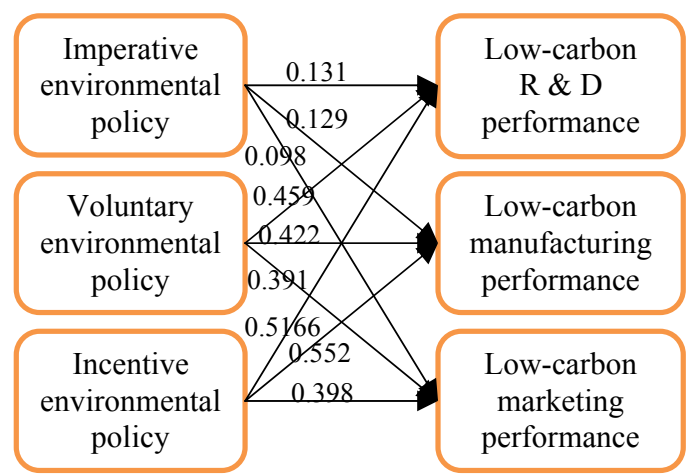

Fig. 1. Test result of environmental impact of policies on innovation performance of manufacturing low-carbon technologies 
Table 7. Environmental policy and manufacturing of low-carbon technological innovation performance model fit index

\begin{tabular}{|c|c|c|c|c|c|c|c|}
\hline Index & $\boldsymbol{\chi}^{\mathbf{2}}$ & df & $\mathbf{P}$ & $\boldsymbol{\chi}^{\mathbf{2}} / \mathbf{d f}$ & RSMEA & CFI & IFI \\
\hline Num & 46.215 & 10.00 & 0.000 & 2.726 & 0.031 & 0.892 & 0.937 \\
\hline
\end{tabular}

Imperative Environmental Policy and Low-carbon Technology Innovation Performance. Test results show that the degree of correlation between imperative environmental policy and low-carbon R\&D performance, low-carbon manufacturing performance, low-carbon marketing performance were $0.131,0.129,0.098$ respectively, which had no significant influence, indicating that hypothesis of 1, 2, 3 does not found. The hypothesis has not been supported by the reasons that summarized as follows: (1)imperative environmental policy aimed at the control and command enterprises strictly implement the relevant policies and regulations, government regulations, for enterprises forced to accept or comply with regulations, serious damage to the economic efficiency of enterprises, curbing the enthusiasm of enterprises' technological innovation; (2)Protection of the environment should promote universal voluntary, independent active cooperation, and imperative environmental policy approach is too rigid, resulting in most enterprises due to excessive government intervention and appears negative attitude.

Voluntary Environmental Policy and Low-carbon Technology Innovation Performance. Test results show that voluntary environmental policy and low-carbon technology innovation performance has a significant degree of correlation, respectively $0.459,0.422,0.391$, indicating hypothesis 4, 5, 6 holds. Voluntary environmental policy to emphasize voluntary implementation of enterprise and involved in government regulations environmental policy activities, so that enterprises can play in environmental protection and environmental management process a more active, willing to take on more social responsibilities subjectively, there is a strong desire for the sustainable development of society for more science and technology innovation.

Incentive Environmental Policy and Low-carbon Technology Innovation Performance. Test results show that incentive environmental policy significantly positive impact on low-carbon technology innovation performance, relevance were $0.516,0.552,0.398$, indicating hypothesis $7,8,9$ holds. Incentive environmental policy aims to promote the effective implementation of economic activities through incentives, the government encouraged enterprises by some technical support measures to develop new technology to solve environmental problems and to provide strong internal impetus for enterprises technology development.

\section{Conclusions}

According to the research, this paper draws the following conclusions: (1)The degree of positive impact of imperative environmental policy for the manufacturing low-carbon technology innovation is not significant, indicating that the government needs to be further amended and improved in terms of laws and regulations, administrative legislation, the development of low-carbon technology innovation is more suitable for manufacturing activities for development of environmental policy system; (2) Voluntary environmental policy and incentive environmental policy both has significant positive impact on the development of manufacturing low-carbon technology innovation, indicating the two play an important role in the development of manufacturing low-carbon technology innovation.

This paper argues that low carbon technology innovation activities of manufacturing industry should combine with government and enterprises, with the government support, the enterprises through their own continuous innovation that to take lower cost, more efficient environmental management measures, and through the low carbon technology innovation to enhancetheir competitiveness, to achieve the purpose of environmental pollution and technological innovation win-win. 


\section{References}

[1] J Zhang: Management Science and Industrial Engineering (MSIE), 2011 International Conference on. IEEE, (2011), p.38-41.

[2] Chiarolla C: Yale/UNITAR Global Conference on Environmental Governance and Democracy, September, (2008), p.4-9.

[3] Jian Gao, Jianfei Wang, Ping Wei in Chinese: Scientific Research Management, vol.25, (2004), p.14-22.

[4] G. Churchill: Journal of Marketing Re-search, vol.16, (1979), p. 64-73. 